\title{
Improving Students' Achievement in Biology using 7E Instructional Model: An Experimental Study
}

\author{
Muhammad Naqeeb UI Khalil Shaheen \\ PhD Scholar, Department of Education, International Islamic University Islamabad \\ naqeeb.shaheen@gmail.com, (corresponding author)
}

\section{Dr. Muhammad Munir Kayani}

Assistant Professor, Department of Education, International Islamic University Islamabad

\section{Doi:10.5901/mjss.2015.v6n4s3p471}

\begin{abstract}
The main purpose of the study was to compare the effectiveness of the instruction based on 7E Instructional Model and Traditional Instructional Model for the teaching of Biology on 9th grade students' achievement. Pretest posttest control group design was used in this study. A total number of 122 ninth grade students (62 boys and 60 girls) from four classes of a biology course of two schools were purposively selected. This study continued for eight weeks. Experimental group (61 students) and control group (61 students) were randomly assigned. The students in the control group were instructed with traditional instructional model, while the students in the experimental group were instructed with 7E Instructional model. A Subject Achievement Test (SAT) and Integrated Science Process Skill Test (ISPST) were used to collect data. Three hypotheses were tested using t-tests and ANCOVA. Independent sample t-test examined that there was a significant difference in the scores of Integrated Science Process Skill Test (ISPST), hence it was used as a covariate. ANCOVA examined that there was a significant difference in the mean post test scores of the groups and gender in terms of students' Subject Achievement Test (SAT) when students' integrated science process skills Test (ISPST) was controlled as a covariate. It was concluded that the $7 E$ instructional model was more effective than the traditional instructional in terms of students' achievements. The study would be helpful for the educators and curriculum developers in implementing new strategies in the classrooms.
\end{abstract}

Keywords: 7E Instructional Model, Students' Achievements, Teaching of Biology, Traditional Instructional Model, Integrated Science Process Skills.

\section{Introduction}

The prime goal of science teaching in the contemporary period is to prepare a student who is ready to compete the global world. It evokes in them the most celebrated learning method of Socrates i.e. discovery through inquiry, thereupon, the process of learning takes place in its true essence. It also helps them to nourish and garnish their knowledge and skills at individual and collective levels and subsequently use these in a broad spectrum. Secondary level science education prepares the students to develop all the three areas i.e. psychomotor, cognitive and affective domains in order to understand the phenomena present in their physical environment. Learning science also helps in developing socially acceptable behavior. Positive responses towards learning, area of subject, and methods of teaching are vital for the students as they strongly influence the process of learning, and the utilization of the concepts gained in the past, but also to find out future possibilities (Safdar, 2007).

The major problems prevailing in the fabrics of education and training provided today are caused by the instructive paradigms used today. In most of the cases, they lack the demands of twenty first century's individuals and their social set up. Therefore, the focus of constructivist framework is the context or the environment in which learning takes place, here, the individuals by integrating the knowledge gained in the past and at present construct unique patterns of understanding (Richardson, 2003).

In traditional teaching approaches, the pertinent decisions, for example; what to learn; in what context; what 
strategies to be used; and how acquisition should be assessed are all made by a single entity known as designer (Gros, 2002). Hence, the main focus of reformation in the field of education is to explore and introduce the ways in which the students are more able to think and reflect critically. Researches done in the past indicated that students bring their individual perception of scientific concepts with them when they approach new learning situation (Postner et al., 1982; Resnik, 1983; Strike, 1983). When the learners construct their own patterns of information, it helps them to ponder the ways in which the creation and organization of these information became possible (Vighnarajah et al., 2008). The instructional model, as a teaching method is concerned about the nature of science which is based on inquiry and the way in which children learn naturally (Cavallo \& Laubach, 2001). Different versions of the instructional models have been emerged on the surface of science curricula with a number of phases ranging from $4 \mathrm{E}$ to $5 \mathrm{E}$ and most recent to $7 \mathrm{E}$. Settlage (2000) stated in this context that the difference in number of phases do not matter as their central goal is same.

A number of subsequent research studies indicated that the approaches which used instructional models based directions helped the pupils in better understanding of the scientific concepts; liking of science and reasoning; and to overcome their wrong interpretation of concepts related to science (Akar, 2005; Balcı et al., 2006; Boddy et al., 2003; Brown \& Sandra, 2007; Cavallo \& Laubach, 1997; Ceylan \& Geban, 2009, Cumo, 1992; Davidson, 1989; Davis, 1978; Gang, 1995; Garcia, 2005; Kaynar et al., 2009; Klindienst, 1993; Lawson \& Thompson, 1988; Lord, 1997; Marek et al., 1994; Mecit, 2006; Odom \& Kelly, 2001; Purser \& Renner, 1983; Renner et al., 1988; Saunders \& Shepardson, 1987; Scharmann, 1991; Shadburn, 1990; Spencer \& Guillaume, 2006; Wilder \& Shuttlewoth, 2005).

The research studies cited above, show that it is vital to develop new strategies to meet the entire goals of biology. If the said instructional strategies are developed and used, and the teachers' passive role and students' active role is promoted by introducing teacher as a guide and facilitator, the problems stated previously can be resolved. A long list of models is available to inculcate classroom strategies. Use of an approach based on instructional model may be involved here (Johnstone \& Mahmoud, 1980; Tekkaya, 2003). The current study used the $7 \mathrm{E}$ instructional model amended by Eisenkraft (2003).

\section{Review of the Related Literature}

\subsection{The 7E Instructional Model}

Eisenkraft (2003) stated seven salient elements: elicit, engage, explore, explain, elaborate, evaluate, and extend as the key components of the said model.

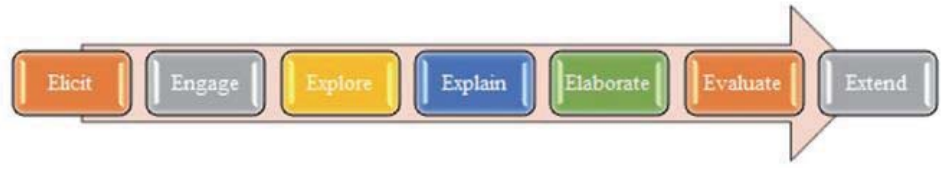

Figure 1. Eisenkraft's 7E Instructional Model (Eisenkraft, 2003)

\subsubsection{Stages of the 7E instructional Model}

The emphasis of tasks included in the stage of elicitation is to make students able to review their prior experiences linked with the learning situations they come across at present.

By using the tasks of engagement stage, teacher takes an attempt to grasp the interest of students and increase their attention, subsequently they get ready to learn. In this way they are motivated to build link between previous concepts and new learning situations. Hence, a logical organization in concepts formation is evident.

The focus of exploratory stage is on creating learning environment for learners which makes observation of scientific processes vivid, develop hypotheses, separate variables, record data, and pattern and organize experimental process, make graphical representation, and arrangement of final outcomes. The role of the teacher is more of a facilitator that $s /$ he is there only to provide queries, inform about paradigms, give feedback, and measure level of comprehension.

Similarly, the purpose served by the tasks carried out during the explanatory stage is to make learners able to express the comprehension of relevant notions. Here the instructor provides guidelines to the learners regarding a broader and clear vision, facilitates them by providing new terminologies in science, and probes the areas which make the learners able to implement these items in interpretation of the findings.

The focus of tasks set for the stage of elaboration is to help learners in implementation of knowledge gained in the 
past when they come across novel situation. It ranges from probing queries to formulating hypothesis for working. Learners are provided assistance regarding comprehension and skill using tasks preset for the stage of evaluation.

Tasks done during the stage of evaluation are considered by the instructors while making students' evaluation of learning on the basis of summative and formative grounds.

Successful practice in transformation of what is learnt becomes possible using tasks of extension stage (Eisenkraft, 2003).

\subsection{Traditional Instructional Model}

According to Roblyer et al. (1997), the process of learning and its outcome is less result oriented in a traditional learning environment when it is compared to an alert learning environment as the learners passively grip and retain knowledge provided by the teacher in a traditional learning environment. The teacher in a traditional learning environment persists the central figure and subsequently in the traditional instructional model. A little amount of learning takes place here though it witnesses information being transmitted (Vighnarajah, et al., 2008). While, the learning is a process of rapid development which is built on constructing individual levels of understanding about the surroundings because of particular external interactions and experiences (Ertmer \& Newby, 1993).

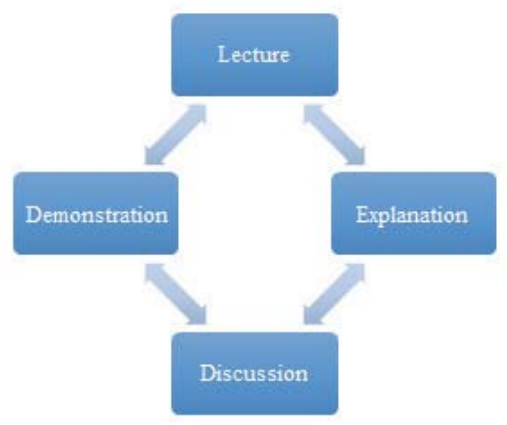

Figure 2. Traditional Instructional Model (Bülbül, 2010)

The major components of Instructional model include lectures, demonstrations and discussion, use of textbooks, strategies depending upon the explanation of teacher without taking into consideration the alternative conception of learners. Numerous studies have shown that student like to participate in a learning environment that changes into a real life like learning environment. Furthermore, traditional learning environment, makes students passive learners that only gives them a chance to retain and grasp information (Vighnarajah et al., 2008).

\subsection{Conceptual Framework}
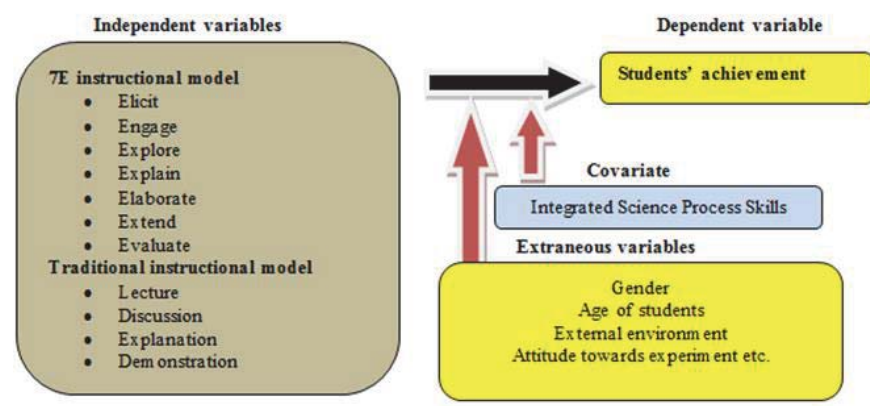

Figure 3. Conceptual framework of the study 
The figure above showed the framework of entire concept. It threw light on the phenomenon in the simplest way and described the researchers' perception regarding the variables that how they built the relationship among them. The achievement of the students in biology was included in the list of dependent variables while the treatments were considered as independent variables. It was supposed that dependent variable might be affected by independent variables and would improve after the treatment. In spite of that, integrated science process skills being a covariate was taken into consideration. Different extraneous variables such as age of students, participants' attitude towards experiment, gender, and external environment were not ignored as well. For instance, Gay (2009) argued to control extraneous variables simultaneously, randomization is the best way alone. Therefore, to control extraneous variables true experimental design was used for the research.

\subsection{Objectives of the Study}

This study was aimed and designed;

1. To compare the effectiveness of instructions, based on $7 \mathrm{E}$ instructional model and traditional instructional model on students' achievement;

2. To investigate the effect of gender on students' achievement.

\subsection{Hypotheses of the Study}

The hypotheses of the study were:

$\mathrm{H}_{0} 1$ : There is no significant difference in the mean scores of students' achievements, based on 7E instructional model and traditional instructional model when integrated science process skills is to be controlled as a covariate;

$\mathrm{H}_{0} 2$ : There is no significant difference in the mean scores of boys and girls with respect to students' achievement when integrated science process skills is to be controlled as a covariate;

$\mathrm{H}_{0} 3$ : There is no significant effect of interaction between gender difference and treatment on students' achievement when integrated science process skills is to be controlled as a covariate.

\subsection{Research Methodology}

Following methods and strategies were adopted during the study.

\subsubsection{Population of the Study}

In this study, all the ninth grade students of the District Rawalpindi who opted Biology as an optional subject were defined as the accessible population of the study.

\subsubsection{Sample of the Study}

Two schools, Government Dennys Higher Secondary School, Rawalpindi, and Government Girls Higher Secondary School, Bagh e Sardaran, Rawalpindi, were purposively selected to conduct experiment. Random sampling technique was used for the selection of the students of both the experimental and control groups. Four classes (two boys and two girls) of grade nine, studying biology course, were selected randomly. The tabular form of the said sample is as follows.

Table 1. Sample of the study

\begin{tabular}{cccc}
\hline Type of School & Experimental Group & Control Group & Total \\
\hline Girls & 30 & 30 & 60 \\
Boys & 31 & 31 & 62 \\
\hline
\end{tabular}

\subsection{The research design of the study}

This study was designed to investigate the effectiveness of Eisenkraft's $7 \mathrm{E}$ instructional model. The researcher implemented pre-test post-test control group design as a type of the true experimental design during study. The systematic description of the said design is given underneath. 


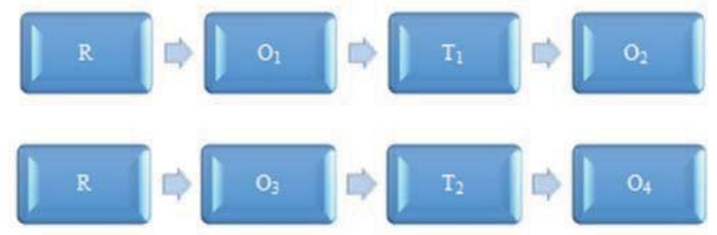

Figure 4. Research Design of the study (Creswell, 2009; Gay, 1996)

At this point

R means "random assignment of subjects to groups",

$\mathrm{O}_{1}$ and $\mathrm{O}_{3}$ stand for "Pre-tests".

$\mathrm{O}_{2}$ and $\mathrm{O}_{4}$ stand for "Pre-tests".

$\mathrm{T}_{1}$ stands for "treatment with the 7E instructional Model".

$T_{2}$ stands for "treatment with Traditional instructional Model".

The experimental groups received instructions based on $7 \mathrm{E}$ instructional model while in the control groups, instructions were given using traditional instructional model. A male and a female teacher having same qualification (M. Sc. Biology and B. Ed) and experience (Five Years) in the selected schools played the role of instructors. Prior to implement the treatment the teachers were told about the aims and objectives of the research, and made acquainted by both traditional instructional model and the $7 \mathrm{E}$ instructional model. The research was spread over eight weeks. There were forty- minute teaching sessions per day for both the groups. In order to test the elements of objectivity and related criteria such as groups' academic achievements in a section of ninth grade Biology course i.e. "Life and Biodiversity", the students of both the groups (Control and Experimental) were administered Integrated Science Process Skills Test (ISPST), and Subject Achievement Test (SAT) as pretests (Table 2 describes research design adapted for the study).

Table 2. Research Design and Instruments

\begin{tabular}{|c|c|c|c|}
\hline Groupings & Pre-tests & Treatments & Post-test \\
\hline Control and Experimental Group & $\begin{array}{c}\text { SAT } \\
\text { ISPST }\end{array}$ & $7 E$ instructional model and Traditional Instructional Model & SAT \\
\hline
\end{tabular}

SAT = Subject Achievement Test

ISPST = Integrated Science Process Skill Test

\subsubsection{Instruments}

The researcher used a teacher made Subject Achievement Test (SAT) and Integrated Science Process Skills Test (ISPST) developed in 2005 by Monica, after taking permission of the author as the research instruments.

\subsection{Data Analysis and Results}

This section represents the results based on the analysis of data.

\subsubsection{Pre-test Scores}

\subsubsection{Subject Achievement Test (SAT)}

Table 3. Descriptive Statistics: Pre-SAT scores

\begin{tabular}{lccccccc}
\hline Group & N & Min & Max & Mean & SD & Skewness & Kurtosis \\
\hline Control & 61 & 4 & 21 & 11.03 & 3.903 & 0.508 & 1.015 \\
Experimental & 61 & 4 & 21 & 11.03 & 3.903 & 0.580 & 1.015 \\
\hline
\end{tabular}

According to the Table 3 there was no difference in students' mean scores with respect to both experimental group 
$(M=11.03, S D=3.903)$ and control group $(M=11.03, S D=3.903)$. It authenticated that the students' distribution was equal in both the groups (Result 1).

Table 4. $t$-test: Pretest scores of SAT

\begin{tabular}{lccccc}
\hline & \multicolumn{2}{c}{ Equality of Variances by Levene's Test } & \multicolumn{3}{c}{ Equality of Means by t-test } \\
\cline { 2 - 6 } & $\boldsymbol{F}$ & $\boldsymbol{S i g}$. & $\boldsymbol{t}$ & $\mathbf{d f}$ & $\boldsymbol{p}$ \\
\hline Equality of variances assumed & 0.000 & 1.000 & 0.000 & 120 & 1.000 \\
Equality of variances not assumed & & & 0.000 & 120 & 1.000 \\
\hline
\end{tabular}

Table 4 represented the conclusions drawn on the basis of independent sample $t$-test analysis of pre-test scores of Subject Achievement Test (Pre-SAT). Equality of Variances by Levene's Test expressed vital results so equal variances were supposed. The results of the independent sample t-test showed no significant mean difference with respect to students' subject achievement test of the control group ( $\mathrm{M}=11.03, \mathrm{SD}=3.903)$ and experimental group ( $\mathrm{M}=11.03$, $\mathrm{SD}=3.903),(t(120)=0.000, p=1.000)$ before the treatment (Result 2$)$.

\subsubsection{ISPST and justification of using ISPST as a covariate}

Table 5. Descriptive Statistics: ISPST

\begin{tabular}{lccccccc}
\hline Group & N & Min & Max & Mean & SD & Skewness & Kurtosis \\
\hline Control & 61 & 10 & 25 & 16.07 & 3.820 & 0.306 & -0.873 \\
Experimental & 61 & 13 & 25 & 18.33 & 3.198 & 0.248 & -0.764 \\
\hline
\end{tabular}

According to the Table 5 students in the experimental group ( $M=18.33, S D=3.198)$ had more skills to solve a scientific problem as compare to the students of control groups ( $M=16.07, S D=3.820$ ) (Result 3 ).

Table 6. $t$-test: Scores of ISPST

\begin{tabular}{lccccc}
\hline & \multicolumn{3}{c}{ Equality of Variances by Levene's Test } & \multicolumn{3}{c}{ Equality of Means by t-test } \\
\cline { 2 - 6 } & $\boldsymbol{F}$ & Sig. & $\boldsymbol{t}$ & $\boldsymbol{d f}$ & $\boldsymbol{p}$ \\
\hline Equality of variances assumed & 1.287 & 0.259 & -3.547 & 120 & 0.001 \\
Equality of variances not assumed & & & -3.547 & 116.389 & 0.001 \\
\hline
\end{tabular}

Table 6 represented the conclusions drawn on the basis of independent sample $t$-test analysis of Integrated Science Process Skills Test (ISPST) scores. Equality of Variances by Levene's Test expressed vital results so equal variances were supposed. The results of the independent sample t-test showed no significant mean difference with respect to students' Integrated Science Process Skills Test (ISPST) scores of the control group ( $M=16.07, S D=3.820$ ) and experimental group ( $M=18.33, S D=3.198),(t(120)=-3.547, p=0.001)$ before the treatment. To control differences existing already in the statistical analysis, students' integrated science process skills test (ISPST) was decided to be used as a covariate (Result 4).

\subsubsection{Post-tests for testing Null Hypotheses}

The section presents the testing of null hypotheses. To test the hypotheses, ANCOVA and t-test were used.

\subsubsection{Ho1: Students' Achievements: 7E instructional model and traditional instructional model}

As the first null hypothesis asserted whether significant difference was found in students' achievements, based on 7E instructional model and traditional instructional model when Integrated Science Process Skills was controlled as a covariate. The first null hypothesis was tested using ANCOVA. Assumptions pertinent to ANCOVA were tested before the implementation of analysis progressed. Since all the necessary assumptions of the ANCOVA were fulfilled, a summary of the results deduced by ANCOVA are shown in Table 8. 
Table 7. ANCOVA: Post-SAT scores of Control and Experimental Groups

\begin{tabular}{cccc}
\hline Source & $\boldsymbol{d f}$ & $\boldsymbol{F}$ & $\boldsymbol{p}$ \\
\hline ISPST & 1 & 2.382 & 0.125 \\
Group & 1 & 54.227 & 0.000 \\
Error & 119 & & \\
\hline
\end{tabular}

The results $(F(1,119)=54.227, p=0.000)$ pointed out that there was a significant mean difference between post mean scores of students' achievements, based on $7 \mathrm{E}$ instructional model and traditional instructional model when integrated science process skills was controlled as a covariate. The experimental group $(N=61, M=16.62, S D=3.967)$ scored on significantly higher level as compare to experimental group $(N=61, M=22.11, S D=3.416)$ (Result 5).

\subsubsection{Ho2: Students' Achievements: Boys and Girls}

According to the second null hypothesis stated previously, there is no significant difference in the mean scores of boys and girls with respect to students' achievement while Integrated Science Process Skills was controlled as a covariate. This very hypothesis was tested using ANCOVA. As done in case of first hypothesis, assumptions pertinent to ANCOVA were tested before the implementation of analysis progressed. Since all the necessary assumptions of the ANCOVA were fulfilled, a summary of the results deduced by ANCOVA are shown in Table 8.

Table 8. ANCOVA: Post-SAT scores of boys and girls

\begin{tabular}{cccc}
\hline Source & $\boldsymbol{d f}$ & $\boldsymbol{F}$ & $\boldsymbol{p}$ \\
\hline Gender & 1 & 5.832 & 0.017 \\
ISPST & 1 & 13.566 & 0.000 \\
Error & 117 & & \\
\hline
\end{tabular}

According to the results $(F(1,119)=5.832, p=0.017)$ of Table 8 , there was a significant difference in the mean scores of boys and girls in terms of their achievement while integrated science process skill was controlled as a covariate. The girls $(\mathrm{N}=60, \mathrm{M}=20.15, \mathrm{SD}=4.4441$ ) scored significantly better as compare to the boys ( $N=62, \mathrm{M}=18.61, \mathrm{SD}=4.667)$ (Result 6).

\subsubsection{Ho3: Students' Achievements: Gender and treatments}

According to the third null hypothesis, there is no significant effect of interaction between gender difference and treatments on students' achievement while Integrated Science Process Skills was controlled as a covariate. This very hypothesis was tested using ANCOVA.

Again, assumptions pertinent to ANCOVA were tested before the implementation of analysis progressed. Since all the necessary assumptions of the ANCOVA were fulfilled, a summary of the results deduced by ANCOVA is shown in Table 9.

Table 9. Students' achievement: Gender difference and treatments

\begin{tabular}{cccc}
\hline Source & $\boldsymbol{d f}$ & $\boldsymbol{F}$ & $\boldsymbol{p}$ \\
\hline ISPST & 1 & 3.940 & 0.049 \\
Group & 1 & 54.089 & 0.000 \\
Gender & 1 & 6.782 & 0.010 \\
Group*Gender & 1 & 0.435 & 0.511 \\
Error & 117 & & \\
\hline
\end{tabular}

The results $(F(1,117)=0.435, p=0.511)$ pointed out there was no significant effect of interaction between gender difference and treatment on students' achievement level while integrated science process skill was controlled as a covariate (Result 7). 


\section{Conclusions}

Conclusions drawn on the basis of above findings are as under:

1. No difference in the mean scores of pre-test in students' subject achievement test (Pre-SAT) in both the control group and experimental group was witnessed. This means that both the groups consisted of equal distribution of students, in addition, the data was distributed normally (Results $1 \& 2$ ).

2. Subjects (treatment group) persisted more skills regarding solution of the problems which they came across as compare to the students of control groups, in addition, the data was distributed normally (Results $3 \& 4$ ).

3. A meaningful gap between post-test average scores of students' achievements, based on 7E instructional model and traditional instructional model was witnessed while students' Integrated Science Process Skill was controlled as a covariate. The experimental group significantly showed better scores than the control group (Result 5).

4. A meaningful change was witnessed in the average scores of boys and girls with respect to students' achievement. The girls obtained significantly higher scores than boys (Result 6 ). Whereas students' skill of process in science was kept under control being a factor of variation.

5. Absence of meaningful impact as a consequence of interaction between difference in gender and experiment on learners' achievement was witnessed. Whereas students' integrated science process skill was controlled as a covariate (Result 7).

\section{Discussions}

Roblyer, et al. (1997) asserted that the process of learning along-with its outcome is more result oriented in an environment which is active as compare to the traditional environment of learning which is passive. Santrock (2001) echoed the similar notions. He thought that learning attains its peak if learners are fully involved in building the foundations of information and comprehension, put in other words, learners are required to participate with agility when it comes to question about how to learn and teach. Subsequently for searching, thinking, and reflecting deeply about facts and figures which they come across. According to Sunal \& Sunal (2003) Strategies involved in investigative teaching consider developmental levels of students and make them able to use the knowledge they acquired in the past when learning new ways of thinking, development of better level in it, and a knowledge about logical power. According to the statistical analysis results cited previously, it became evident that 7E instructional model produced significantly better acquisition level of students' achievements than traditional instructional model. While analysis of Post-SAT results also strengthened the claim. One question is still there to answer which was raised as a result of a research study that teachers remained indecisive about the selection of one or more stage of instructional model based on 7E needed application (Yenilmez \& Ersoy, 2008), however, there are other evidences that support the effectiveness of the instructions based on instructional models (Bybee et al., 2006; Perrier \& Nsengiyunva, 2003; Sasmaz \& Tezcan, 2009).

One of the purposes of the research centered on the investigation of any meaningful change is based on gender difference regarding academic achievements. Different research studies had shown that gender difference plays a vital role in acquisition of scientific concepts, for instance, a research claimed significant gender difference (Cavallo et al., 2004). In 1994, Fraser and Young found meaningful change in boys' success rate in biology when seen in the perspective of gender differentiation. On the other hand, Soyibo (1999) viewed that girls' performance level was on higher level when tested for identification of mistakes in giving labels (biology). Alparslan et al. (2003) conducted an experimental research. Their research unfolded potential difference produced by varied methods of experiment (for instance, one instruction based on change in concept whereas another based on tradition) when measured in the perspective of differentiation in gender. During the said research, subjects selected were studying at grade eleven. The subsequent assessment of comprehension was obtained by the topic of "Respiration". When the outcomes of male and female subjects were compared for "Genetics", there was no visible gap to be found (Doğru and Tekkaya, 2008). Likewise, no gender differentiation was found when Jamacian learners at grade eight were assessed for the notions regarding the topics of "Nutrition" and "Reproduction in Plants" (Ugwu and Soyibo, 2004). Moreover, similar findings were attained in the studies of other researchers (Azizoğlu, 2004; Bülbül, 2010; Dimitrov, 1999; Hupper et al., 2002; Shepardson \& Pizzini, 1994; Thompson \& Soyibo, 2002).

\section{Recommendations}

The central aim of teaching science today is to promote purposeful addition into the knowledge. To meet this goal it is 
pertinent to bridge the gap between novel thoughts and past information. This ability helps the learners to grasp the comprehension of new materials and then use it for explanation of situations, they are supposed to face. Thereupon, teachers should take care of the information level of the students gained in the past enhance purposeful learning process. According to the findings of this study, $7 \mathrm{E}$ instructional model proved a better one in scientific training of the students.

Promotion of purposeful addition into the knowledge has established its status as a kind of methodology based on instructions. Therefore, instructions which make students able to connect and transfer information and visualize events by implementing the 7E instructional model and prevent formation of delusions may help students to get rid of these problems. Therefore, the strategy of inquiry teaching considers students' developmental levels and makes them able to use their prior knowledge as they gain new thought processes, develop higher levels of thinking, and became known to their own reasoning. Consequently, science curriculum planners, textbook setters and finally the teachers should be aware of the role of the 7E instructional model in science education. Therefore, teachers can pattern their instructions in a way that it is not going to create new misconceptions. Moreover, school administrations or ministry of national education are encouraged to arrange teachers' seminars and training workshops about 7E instructional model, where teachers are provided chances to improve their personal skills. Additionally, school administrations are advised to use their influential role in making their teachers ready to attend these programmers.

In understanding science education, science process skills of students are highly effective. So, teachers and parents should provide chances to their pupils to improve the said skills. Curriculum developers and administrators must try to implement the 7E instructional model to develop scientific thinking among the students.

\section{References}

Akar, E. (2005). Effectiveness of $5 E$ learning model on students' understanding of acid-base concepts. Thesis: Master of Education. Turkey: Middle East Technical University.

Alparslan, C., Tekkaya, C., \& Geban, O. (2003). Using the conceptual change instruction to improve learning. Journal of Biological Education, 37, 133-137.

Azizoğlu, N. (2004). Conceptual Change Oriented Instruction and Students' misconceptions in gases. Thesis: PhD in Education, Ankara: Middle East Technical University.

Balcı, S., Çakıroğlu, J. \& Tekkaya, C. (2006). Engagement, Exploration, Explanation, Extension, and Evaluation (5E) Learning Cycle and Conceptual Change Text as Learning Tools. Biochemistry and Molecular Biology Education, 34(3), 199-203.

Boddy, N., Watson, K. \& Aubusson, P. (2003). A trial of 5Es: A referent model for constructivist teaching and learning. Research in Science Education. 33 (1), 27-42.

Brown, P. L. \& Sandra, K. A. (2007). Examining the Learning Cycle. Science and Children, 58-59.

Bülbül Y. (2010). Effects of 7E Learning Cycle Model Accompanied with Computer Animations on Understanding of Diffusion and Osmosis Concepts. Thesis: PhD in Secondary Science and Mathematics Education. Turkey: Middle East Technical University.

Bybee, R. W., Taylor, A. J., Gardner, A., Van Scotteer, P., Powell, J. C., Westbrook, A., \& Landes, N. (2006). The BSCS 5E Instructional Model: Origins, Effectiveness and Applications. Full report. Colorado Springs.

Cavallo, A. M. L. \& Laubach, T. A. (2001). Students' Science Perceptions and Enrollment Decisions in Differing Learning Cycle Classrooms. Journal of Research in Science Teaching, 38(9), 1029-1062.

Cavallo, A. M. L., Rozman, M., \& Potter, W. H. (2004). Gender differences in learning constructs, shifts in learning constructs, and their relationship to course achievement in a structured inquiry, yearlong college physics course for life science majors. School Science and Mathematics, 104, 288-300.

Cavallo, A.M.L. \& Laubach, T.A. (2001). Students' Science Perceptions and Enrollment Decisions in Differing Learning Cycle Classrooms. Journal of Research in Science Teaching, 38(9), 1029-1062.

Ceylan, E. \& Geban, Ö. (2009). Effects of 5E Learning Cycle Model on understanding of state matter and solubility concepts. Hacettepe: University Journal of Education.

Creswell, J. W. (2009). Research Design. London: Sage Publications, Inc.

Davidson, M. A. (1989). Use of learning cycle to promote cognitive development. Thesis: PhD in Education. USA: Purdue University.

Davis, J. O. (1978). Effects of three approaches to science instruction on the science achievement, understanding, and attitudes on selected fifth and sixth grade students. Dissertation Abstracts International, 39, 211A.

Dimitrov, D. M. (1999). Gender differences in science achievement: Differential effect of ability, response format, and strands of learning outcomes. School Science and Mathematics, 99, 445-450.

Doğru A. P. \& Tekkaya, C. (2008). Promoting Students' Learning in Genetics with the Learning Cycle. Journal of Experimental Education.

Eisenkraft, A. (2003). Expanding the 5E Model. The Science Teacher, 70(6), 56-59.

Ertmer, P. A., \& Newby, T. J. (1993). Behaviorism, cognitivism, constructivism: Comparing critical features from an instructional design perspective. Performance Improvement Quarterly, 6 (4), 50-72.

Gang, S. (1995). Removing preconceptions with a "learning cycle". The Physics Teacher, 33 (6), 346-354.

Gay, L. R. (1996). Educational Research competencies for Analysis and Application. New Jersey: Merrill. 
Gay, L. R. (2009). Educational Research competencies for Analysis and Application. Islamabad: National Book Foundation.

Gros, B., (2002). Constructivism and Designing Virtual Learning Environment. Society for Information Technology and Teacher Education, 950-954.

Hupper, J., Lomask, S. M., \& Lazarowitz, R. (2002). Computer simulations in the high school: Students' cognitive stages, science process skills and academic achievement in microbiology. International Journal of Science Education, 24, 803-821.

Johnstone, A. H., \& Mahmond, N. A. (1980). Isolating topics of high perceived difficulty in school biology. Journal of Biological Education, 14, 163-166.

Kaynar, D., Tekkaya, C. \& Cakiroglu, J. (2009). Effectiveness of 5E Learning Cycle Instruction on Students' Achievement in Cell Concept and Scientific Epistemological Believes. Hacettepe University Journal of Education, 37, 96-105.

Klindienst, D. B. (1993). The Effects of Learning Cycle Lessons Dealing with Electricity on the Cognitive Structures, Attitude toward Science, Achievement of Urban Middle School Students. Thesis: PhD in Education, USA: Pennsylvania State University.

Lawson, A. E. \& Thompson, L. D. (1988). Formal reasoning ability and misconceptions concerning genetics and natural selection. Journal of Research in Science teaching, 25 (9), 733-746.

Lord, T. R. (1997). A comparison between traditional and constructivist teaching in college biology. Innovative Higher Education, 21 (3), 197-216.

Marek, E. A., Cowan, C. C., \& Cavallo, A. M. L. (1994). Students' misconception about diffusion: How can they be eliminated? American Biology Teacher, 56, 74-78.

Mecit, Ö. (2006). The effect of 7E learning cycle model on the improvement of fifth grade students' critical thinking skills. Thesis: PhD in Education. Turkey: Middle East Technical University.

Odom, A. L. \& Kelly, P. V. (2001). Integrating Concept Mapping and the Learning Cycle to Teach Diffusion and Osmosis Concepts to High School Biology Students. John Wiley \& Sons, Inc. Science Education, 85, 615- 635.

Perrier, F. \& Nsengiyumva, J. B. (2003). Active science as a contribution to the trauma recovery process. Preliminary indications with orphans for the 1994 genocide in Rwanda. International Journal of Science Education, 25, 1111-1128.

Postner, G. J., Strike, K. A., Hewson, P. W. \& Gertzog, W. A. (1982). Accommodation of a scientific conception: Toward a theory of conceptual change. Science Education, 66 (2), 195-209.

Purser, R. K. \& Renner, J.V. (1983). Results of two tenth grade biology teaching procedures. Science Education, 67 (1), $85-98$.

Renner, J.W., Abraham, M.R., \& Birnie, H. H. (1988). The necessity of each phase of the learning cycle in teaching high-school physics. Journal of Research in Science Teaching, 25, 39-58.

Resnik, L. (1983). Mathematics and science learning: A new conception. Science, 220, 477-478.

Richardson, V. (2003). Constructivist pedagogy. Teachers College Record, 105 (9), pp. 1623-1640.

Roblyer, M. D., Edwards, J., \& Havriluk, M. A. (1997). Integrating educational technology into teaching. Upper Saddle River, New Jersey: Prentice-Hall, Inc.

Safdar, M. (2007). A Comparative Study of Ausubelian and Traditional Methods of Teaching Physics at Secondary School Level in Pakistan. Thesis: PhD in Education. Islamabad: National University of Modern Languages.

Santrock, J. W. (2001). Educational psychology: International edition. New York: McGraw-Hill Companies, Inc.

Saşmaz, F. \& Tezcan, R. (2009). The Effectiveness of the Learning Cycle Approach on Learners' Attitude toward Science in Seventh Grade Science Classes of Elementary School. Elementary Education Online, 8(1), 103-118.

Saunders, W. L. \& Shepardson, D. (1987). A comparison of the concrete a formal science instruction upon science achievement and reasoning ability of sixth grade students. Journal of Research in Science Teaching, 24 (1), 39-51.

Scharmann, L. C. (1991). Teaching Angiosperm Reproduction by means of the learning cycle. School Science and Mathematics, 91 (3). 100-104.

Settlage, J. (2000). Understanding the Learning Cycle: Influences on Abilities to Embrace the Approach by Preservice Elementary School Teachers. Science Education, 84(1), 43-50.

Shadburn, R.G. (1990). An evaluation of a learning cycle intervention method in introductory physical science laboratories in order to promote formal operational thought process. Thesis: PhD in Education. USA: University of Mississippi.

Shepardson, D. P., \& Pizzini, E. L. (1994). Gender, achievement, and perception toward science activities. School Science and Mathematics, 94, 188-193.

Soyibo, K. (1999). Gender differences in Caribbean students' performance on a test of errors in biological labeling. Research in Science and Technological Education, 17, 75-82.

Spencer, B. H. \& Guillaume, A. M. (2006). Integrating curriculum through the learning cycle: Content-based reading and vocabulary instruction. The Reading Teacher, 60 (3), 206-219.

Strike, K. A. (1983). Misconceptions and conceptual change: Philosophical reflections on the research program. International Seminar on Misconceptions in Science and Mathematics, Cornell University, 67-78.

Sunal, D. W., \& Sunal, C. S. (2003). Science in elementary and middle school. In L. A. Montgomery (Ed.), the learning cycle. Upper Saddle River, NJ: Merrill-Prentice Hall.

Tekkaya, C., (2003). Remediating High School Students' Misconceptions Concerning Diffusion and Osmosis through Concept Mapping and Conceptual Change Text. Research in Science and Technological Education, 21 (1), 5-15.

Thompson, J., \& Soyibo, K. (2002). Effects of lecture, teacher demonstrations, discussion and practical work on $10^{\text {th }}$ graders' attitudes to chemistry and understanding of electrolysis. Research in Science and Technological Education, 20, 25-37.

Ugwu, O., \& Soyibo, K. (2004). The effects of concept and mind mappings under three learning modes on Jamaican eighth graders' 
knowledge of nutrition and plant reproduction. Research in Science and Technological Education, 22, 41-57.

Vighnarajah, Luan, \& Bakar (2008). The Shift in the Role of Teachers in the Learning Process. European Journal of Social Sciences, $7(2), 33-36$.

Wilder, M. \& Shuttlewoth, P. (2005). Cell Inquiry: A 5E learning cycle lesson. Science Activities, 44 (4), 37-43.

Yenilmez, K \& Ersoy, M. (2008). Opinions of Mathematics Teacher Candidates towards Applying 7E Instructional Model on Computer Aided Instruction Environments. International Journal of Instruction, 1(1), 58.

Young, D. J., \& Fraser, B. J. (1994). Gender differences in science achievement: Do school effects make a difference? Journal of Research in Science Teaching, 31, 857-871. 